\title{
枠基礎の鉛直支持力機構に関する理論および模型実験結果との 比較検討 \\ THEORY ON BEARING CAPACITY OF FRAMED FOUNDATION AND COMPARISON WITH MODEL TEST RESULTS
}

\author{
伊藤淳志*,山肩邦男** \\ Atsushi ITO and Kunio YAMAGATA
}

\begin{abstract}
Framed Foundation is made to confine lateral movement of the soil under the footing and increase the bearing capacity of the ground. This paper describes a theory on the bearing capacity and consideration on the load-settlement behavior of Framed Foundation. The conclusions are summarized as follows.

(1) The relationships between load and settlement of the footing, the distributions of settlement and axial force of inside soil at the model test are expressed exactly by using authors' theory which is led by finite deference method.

(2) On the bearing capacity, influence of the frictional resistance and the point resistance of frame are small, and the compressibility of inside soil and subsoil are dominating. The bearing capacity of Framed Foundation is equal to the spread foundation which depth is equal to that of frame.

(3) The settlement of the footing is sum of compression of inside soil and settlement of subsoil. The distributions of settlement of the ground can be shown as Fig. 11 and Fig. 12 in compliance with the depth of frame.
\end{abstract}

Keywords : foundation, bearing capacity, vertical load, settlement, model test

1. 序

基礎フーチング直下の地盤の周囲に，土の側方移動を 拘束する枠を設けることによって，地盤の鉛直支持力を 增大させる型式の基礎を,筆者らは枠基礎と呼んでいる。 この枠基礎の鉛直支持力機構を解明するため，これまで に枠内土の挙動に関する基礎実験”や模型枠基礎の鉛直 載荷実験”を行ってきた。今回，これらの実験によって 分かった支持力特性を考慮して, 砂地盤を対象とした枠 基礎の鉛直支持力機構の理論解を誘導したので，本論に おいて報告する。

枠基礎と同種の基礎に関する理論的研究としては, こ れまでに発表されたものは比較的少なく, 南 ${ }^{31}$, Kuzmanović ら ${ }^{41}$, Broms ら ${ }^{51} の$ 文献に, 極限状態での応力の 釣合いを考えた支持力式や土の体積王縮係数を導入した 沈下量の算定式が提案されている程度であった。

筆者らは文献”において，鋼管で側方拘束された砂柱 の圧縮挙動に関して, 差分方程式を誘導する方式による 理論解を提示し，計算値と実駼結果とを比較することに よって,. 理論解の妥当性の検討を行った。その結果, 本
解析法によって，砂柱の応力および変形の状態をかなり よい精度で表現できることが分かった。本論における枠 基礎の鉛直支持力機構の理論解は，上記の解析法を基本 として, さらに枠および枠内土の先端抵抗特性，および 枠と外周地盤との摩擦抵抗特性をも考慮できるように搪 張したものである。

本論では，まず理論式の誘導過程を示し，次いで模型 実験2を対象とした数值計算によって, 本理論解の妥当 性の検討を行う。さらに，実験および解析結果をもとに， 枠基礎の荷重一沈下特性に関する総括的な考察を行うこ ととした。

\section{2. 理論解}

\section{1 基本的仮定}

ここで対象とする枠基礎の型式として，以下の 2 種類 を考愿する。

(1) 基礎フーチングと枠とが分離しており, 建物荷重が 枠内土のみに作用する「分離型」(図一1(a))

（2）基礎フーチング直下に枠が設置されており，建物荷
* 関西大学 助手.工修

** 関西大学 教授・工博
Research Associate of Kansai University, M. Eng.

Professor of Kansai University, Dr. Eng. 


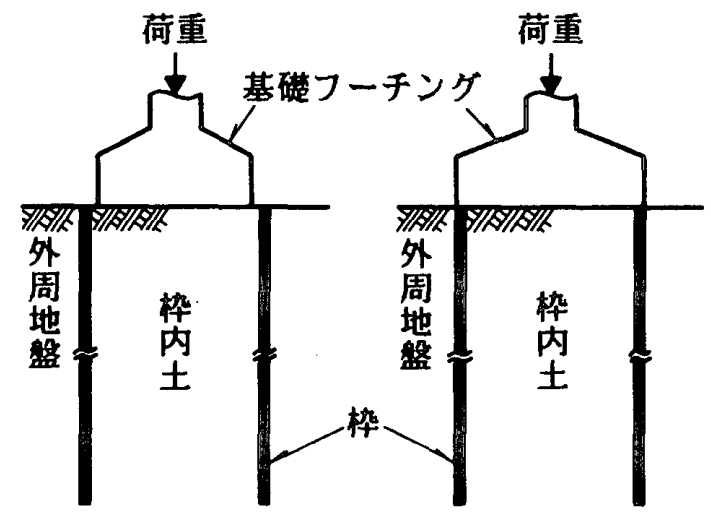

（a）分離型

（b）一体型

图一1 枠基礎の型式

重が枠と枠内土とに同時に作用する「一体型」（図一1 (b))

枠基礎の支持力に関連する要素は，枠，枠内土および 外周地盤の 3 つに大別できる。理論式の誘導にあたり， これらの要素の特性および要素相互間の特性として, 以 下の仮定をおくこととした。

i）枠は完全弾性体とする。

ii）执内土の鉛直応力 $\sigma_{v}$ と鉛直ひずみ $\varepsilon_{v}$ とは，図一2 (a) のごとく非線形関係を示すものとする。この際， $\sigma_{v}$ は同一深さにおいては等分布とし，土圧係数 $K$ は一定 と仮定する。側方拘束された砂柱の圧縮特性に関する筆 者ら"やSchultze ら゙の実験結果によれば， $\sigma_{v}$ と $\varepsilon_{v}$ と は両対数紙上でほぼ直線関係を示し， $\sigma_{v}$ の增加に伴っ て土の剛性は増大する。したがって，この特性を表現で きるように同図の曲線関係を仮定した。また，枠と地盤 との摩擦抵抗の評価に必要な土王係数 $K$ については, 枠は水平方向に変位しないものとして, 静止状態を仮定 した。この場合, 荷重の増加過程においては，Kはほ ぼ一定値とみなしてよかろうう 。

iii）枠先端および枠内土先端に非線形のばねを想定し， これらの抵抗 $p_{p}$ および $p_{s p}$ がそれぞれの视下量 $S_{p}$ お よび $S_{s p}$ との間に示す関係を, 図一2(b) のごとく仮定 する。枠先端之枠内土先端とでは, それらの剛性, 断面
形状，中心からの距離等によって，抵抗と沈下量との関 係は異なる101,111。したがって，各々独立した非線形ばね を考えた。なお，枠先端肉厚部が薄く，その抵抗を無視 できる場合はこれを 0 とする。

iv）枠と外周地盤および枠と枠内土との間には摩擦抵抗 が作用するものとし，これらの摩擦応力を $f_{o}$ および $f_{i}$ とする。 $f_{o}$ と枠の沈下量 $S$ との関係および $f_{i}$ と枠一枠 内土間の相対変位 $\Delta S$ との関係として, 図一 $2(\mathrm{c})$ のご とく非線形関係を仮定する。一般に，摩擦応力は地盤の 応力の大きさによって，その最大值が規定される。した がって， $f_{0} \sim S$ 関係については， $f_{0}$ の最大值を地表面 加の深さに 1 次比例するものと考えて, 曲線形状を仮 定した。しかし，枠之枠内土との抵抗については，荷重 の増加に伴って枠内土の応力が增大するため, $f_{i} \sim \Delta S$ 関係は一義的には定まらない”。そこで，本理論では各 荷重段階において，枠内土の水平応力 $\sigma_{h}\left(=K \sigma_{v}\right)$ に対 応した $f_{i}-\Delta S$ 関係曲線が成立つものと仮定することと した。

\section{2 理論式の誘導}

図一3(a) のごとく枠および地盤を $n$ 層に区分し，各 区間での釣合い方程式を誘導する。なお，ここで使用す る記号を表一1に示しておく。

まず，枠について以下の式が成立つ（図一3(b)，(c) 参照)。ただし，圧縮力および沈下量を正とする。

$$
-\frac{S(j+1)-S(j)}{h(j)}=\frac{R(j+1)+R(j)}{2 A E} .
$$

ただし，

$$
\begin{aligned}
R(j)= & R(1)-\sum_{l=1}^{j-1}\left\{\frac{f_{i}(l+1)+f_{i}(l)}{2} \psi_{i}\right. \\
& \left.+\frac{f_{o}(l+1)+f_{o}(l)}{2} \psi_{o}\right\} h(l) \cdots
\end{aligned}
$$

ここに, $h(l)$ の変化は無視するものとした。また，

分離型の場合 : $R(1)=0$

一体型の場合 : $R(1)=\alpha P_{0}(0 \leqq \alpha \leqq 1)$

（2）式を（1）式に代入すると次式となる。

$$
-\frac{S(j+1)-S(j)}{h(j)}=\frac{1}{2 A E}[2 R(1)
$$

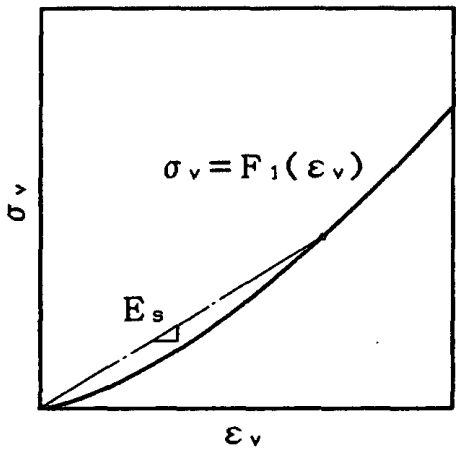

（a）枠内土の鉛直応力 〜鉛直ひずみ関係

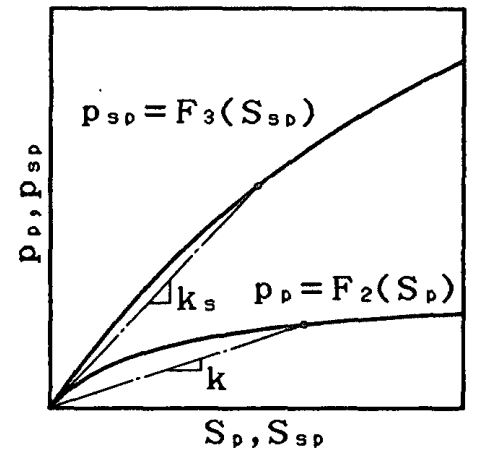

（b）枠㧈よび枠内土の先端抵抗 ～先端沈下量関係

图一2 基本的仮定

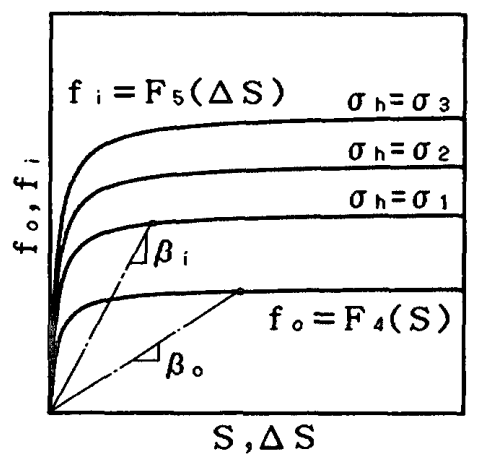

（c）枠と地盤との間の摩擦応力 ～相対変位関係 


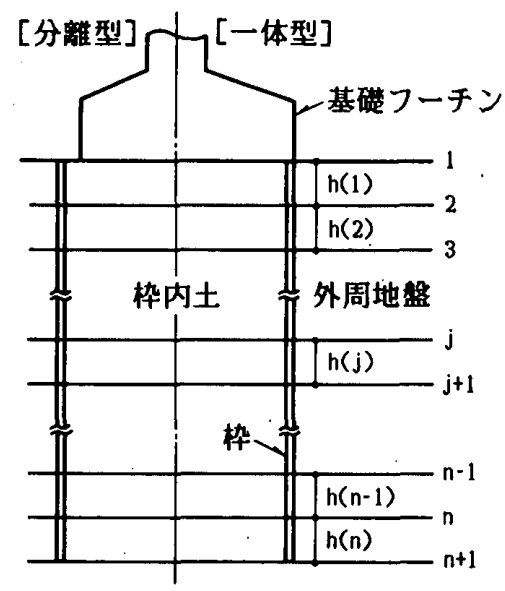

(a)

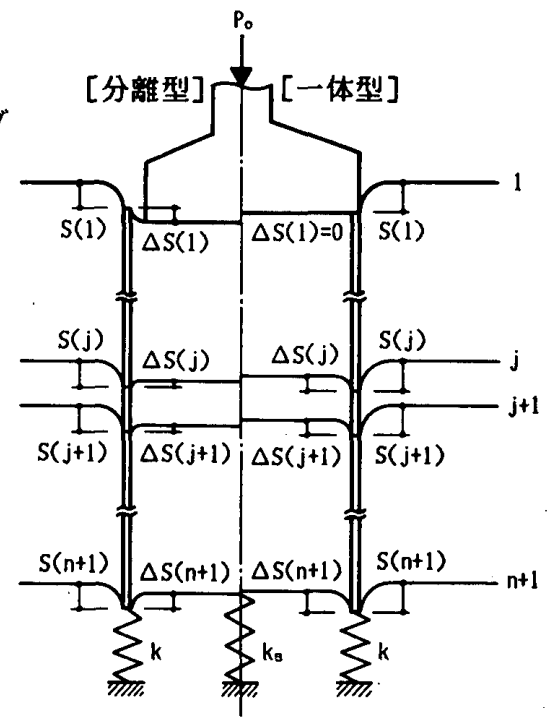

(b)
（枠内土）（枠）（外周地盤）

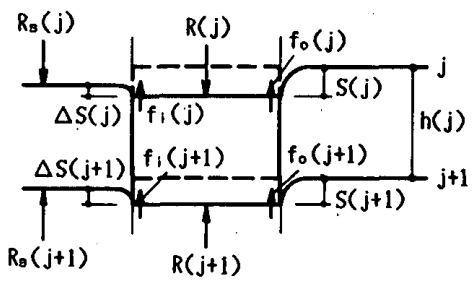

(c)

図一3 解析モデル

$$
\begin{aligned}
& -\sum_{l=1}^{j-1}\left\{f_{i}(l+1)+f_{i}(l)\right\} \psi_{i} h(l) \\
& -\sum_{l=1}^{j-1}\left\{f_{o}(l+1)+f_{o}(l)\right\} \psi_{o} h(l) \\
& -\frac{f_{i}(j+1)+f_{i}(j)}{2} \psi_{i} h(j) \\
& \left.-\frac{f_{o}(j+1)+f_{o}(j)}{2} \psi_{o} h(j)\right] \ldots
\end{aligned}
$$

ただし， $j=1$ の場合は，

$$
\begin{aligned}
-\frac{S(2)-S(1)}{h(1)}= & \frac{1}{2 A E}\left\{2 R(1)-\frac{f_{i}(2)+f_{i}(1)}{2} \psi_{i} h(1)\right. \\
& \left.-\frac{f_{o}(2)+f_{o}(1)}{2} \psi_{o} h(1)\right\} \cdots \cdots \cdots(5)
\end{aligned}
$$

\begin{tabular}{|c|c|c|}
\hline 毁 守 & 単 位 & 融 \\
\hline$P_{0}$ & kgf & 载荷荷重 \\
\hline$R(j), R_{s}(j)$ & kgf & j点ての摔および忰内土の軸方向力 \\
\hline$\alpha$ & 0 & $\mathrm{R}(1) / \mathrm{P}_{0} \quad(0 \leqq \alpha \leqq 1)$ \\
\hline $\mathrm{A}, \mathrm{A}_{3}$ & $\mathrm{~cm}^{2}$ & 伜および抛内土の断面積 \\
\hline$E, E_{s}(j)$ & $\mathrm{kgf} / \mathrm{cmr}^{2}$ & 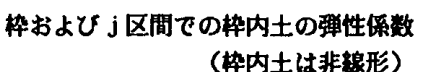 \\
\hline $\begin{array}{c}\boldsymbol{\psi}_{\mathrm{i}}, \boldsymbol{\psi}_{\mathrm{o}} \\
\mathrm{h}(\mathrm{j})\end{array}$ & $\begin{array}{l}\mathrm{cm} \\
\mathrm{cm}\end{array}$ & $\begin{array}{l}\text { 枠の内周長さおよび外周辰さ } \\
\text { j区間の区間長さ }\end{array}$ \\
\hline$S(j)$ & $\mathrm{cm}$ & $\mathrm{j}$ 点での淬の沈下量 \\
\hline$\Delta S(j)$ & $\mathrm{cm}$ & $\mathrm{j}$ 点での枠と枅内土との相対变位 \\
\hline$f_{i}(j)$ & $\mathrm{kgf} / \mathrm{cm}^{2}$ & 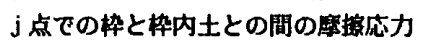 \\
\hline$f_{\circ}(j)$ & $\mathrm{kgf} / \mathrm{cm}^{2}$ & $\mathrm{j}$ 点 の伜と外周地盤との間の度推応力 \\
\hline $\mathrm{k}, \mathrm{k}_{\mathrm{s}}$ & $\mathrm{kgf} / \mathrm{cm}^{3}$ & $\begin{array}{r}\text { 执先端および伜内土先端のばね常数 } \\
\text { (非婂形) }\end{array}$ \\
\hline$\beta_{i}(j), \beta_{0}(j)$ & $\mathrm{kgf} / \mathrm{cm}^{3}$ & $f_{i}(j) / \Delta S(j), f_{o}(j) / S(j)$ \\
\hline
\end{tabular}

枠先端における非線形のばねを考えると， $R(n+1)=$ $A k S(n+1)$ なる境界条件より次式が成立つ。

$$
\begin{aligned}
A k S(n+1)= & R(1)-\sum_{l=1}^{n}\left\{\frac{f_{i}(l+1)+f_{i}(l)}{2} \psi_{i}\right. \\
& \left.+\frac{f_{o}(l+1)+f_{o}(l)}{2} \psi_{0}\right\} h(l) \cdots \\
& \text { 表一1 記号一覧 }
\end{aligned}
$$

次に, 枠内土についても同様にして,

$$
\begin{aligned}
& -\frac{\{S(j+1)-\Delta S(j+1)\}-\{S(j)-\Delta S(j)\}}{h(j)} \\
& =\frac{R_{s}(j+1)+R_{s}(j)}{2 A_{s} E_{s}(j)} \ldots \ldots \ldots \ldots \ldots \ldots \ldots \ldots \ldots \ldots \ldots \ldots \ldots \ldots \ldots \ldots \ldots
\end{aligned}
$$

ただし，

$$
R_{s}(j)=R_{s}(1)+\sum_{i=1}^{j-1} \frac{f_{i}(l+1)+f_{i}(l)}{2} \psi_{i} h(l) \cdots \cdots
$$

ここに,

$$
\left.\begin{array}{l}
\text { 分離型の場合 }: R_{s}(1)=P_{0} \\
\text { 一体型の場合 }: R_{s}(1)=(1-\alpha) P_{0}
\end{array}\right\}
$$

（8）式を（7）式に代入すると次式となる。

$$
\begin{aligned}
- & \frac{\{S(j+1)-\Delta S(j+1)\}-\{S(j)-\Delta S(j)\}}{h(j)} \\
= & \frac{1}{2 A_{s} E_{s}(j)}\left[2 R_{s}(1)+\sum_{l=1}^{j-1}\left\{f_{i}(l+1)+f_{i}(l)\right\} \psi_{i} h(l)\right. \\
& \left.+\frac{f_{i}(j+1)+f_{i}(j)}{2} \psi_{i} h(j)\right] \cdots \cdots \cdots \cdots \cdots \cdots \cdots(10)
\end{aligned}
$$

ただし，j=1の場合は，

$$
\begin{aligned}
& -\frac{\{S(2)-\Delta S(2)\}-\{S(1)-\Delta S(1)\}}{h(1)} \\
& =\frac{1}{2 A_{s} E_{s}(1)}\left\{2 R_{s}(1)+\frac{f_{i}(2)+f_{i}(1)}{2} \psi_{i} h(1)\right\} \cdots
\end{aligned}
$$

枠内土先端における境界条件 $R_{s}(n+1)=A_{s} k_{s}\{S(n+1)$ $-\Delta S(n+1)\}$ より次式が成立つ。

$$
\begin{aligned}
& A_{s} k_{s}\{S(n+1)-\Delta S(n+1)\}=R_{s}(1) \\
& \quad+\sum_{l=1}^{n} \frac{f_{i}(l+1)+f_{i}(l)}{2} \psi_{i} h(l) \ldots \ldots . .
\end{aligned}
$$

ここで, 摩擦応力と相対変位あるいは沈下量との間に は以下の関係がある。

$$
\begin{aligned}
& f_{i}(j)=\beta_{i}(j) \Delta S(j) \\
& f_{o}(j)=\beta_{o}(j) S(j)
\end{aligned}
$$

ただし，一体型の場合， $\Delta S(1)=0$ 。したがって， $f_{i}(1)=$ 
0 。

以上より, 分離型の場合, $S(j)$ および $\Delta S(j)(j=1$ $n+1)$ の $(2 n+2)$ 個の未知数に対して, $(2 n+2)$ 個の連 立方程式が成立つ。また, 一体型の場合, $S(j)(j=1$ $n+1), \Delta S(j)(j=2 \sim n+1)$ および $\alpha$ の $(2 n+2)$ 個の未 知数に対して，(2n+2)個の連立方程式が成立つ。解法 としては，基本的仮定で述べたごとく枠内土の鉛直応力 とひずみとの関係, 摩擦応力と相対変位との関係および 先端抵抗と先端沈下量との関係が非線形であるため, 以 下の手順により解を求める。

i ) $E_{s}(j), \beta_{i}(j), \beta_{o}(j), k$ および $k_{s}$ に初期值（例えば, 関係曲線上の単位の応力に対応した点と原点とを結んだ 直線の勾配）を与えて連立方程式を解き， $S(j)$ および $\Delta S(j)$ を求め, このときの $j$ 点での各応力を計算する。 ii）すべてのj区間での枠内土の鉛直応力〜ひずみ関 係，すべての $j$ 点での摩擦応力〜相対変位関係および 先端抵抗～先端沈下量関係が，仮定した曲線関係を満足 していれば求める解である。

iii）上記の関係中，1つでも満足しない $j$ 区間または $j$ 点があれば，その計算段階でのひずみまたは沈下量に対 応した関係曲線上の勾配を新たな常数として再計算を行 う。この方法を繰り返し行い, 最終的に ii ）の関係がす べて満足された状態が得られれば，これが求める解であ る。

\section{3. 解析例}

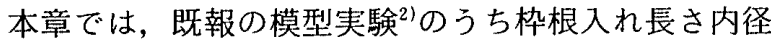
比 $L / D=4$ の分離型および一体型の載荷試験を対象と した数値計算を行い，夹験結果との比較検討を行う。

模型実験は, 内径 $\phi 1480 \mathrm{~mm}$, 深さ $1700 \mathrm{~mm}$ の鋼製 土槽内に作製した砂地盤に，内径 $D=150 \mathrm{~mm}$, 外径 $162 \mathrm{~mm}$, 先端肉厚 $6 \mathrm{~mm}$ のアルミニウム製二重管 (各 厚さ $0.8 \mathrm{~mm})$ の模型枠を建込み, 鉛直載荷試験を行っ たものである。地盤は，1.2 $\mathrm{mm}$ のろるい目を通過した 淀川砂を土槽下部からの圧力水でボイリングさせた後, 自然排水することによって作製した。その結果，単位体 積重量 $\gamma=1.475 \mathrm{gf} / \mathrm{cm}^{3}$, 相対密度 $D_{r}=35 \%$, 含水比 $w=4.57 \%$ のほぼ均一な地盤となっている。なお，模 型奏験の詳細については文献 2) を参照されたい。

\section{1 解析に用いた諸常数}

枠の弾性係数は模型枠の軸方向加力検定試験によって 得られた $E=7.3 \times 10^{5} \mathrm{kgf} / \mathrm{cm}^{2}$ を採用した。また，地盤 の諸常数は以下の方法により決定した。

(1) 枠内土の鉛直応力 $\sigma_{v}$ と鉛直ひずみ $\varepsilon_{v}$ との関係

図一4は，模型実験での枠のひずみより算出した枠内 土の軸方向力分布および沈下板による沈下量分布を滑ら

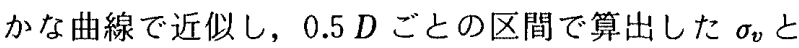
$\varepsilon_{v}$ との関係を, 両対数紙上に示したものである。ただし，
軸方向力・沈下量ともに值が小さく，計算誤差の大きい 第 1 荷重階および載荷板近傍の局部的な応力の乱れが大 きい最上部の $0.5 \mathrm{D}$ の区間"については除外してある。 同図より，実験值にはある程度のばらつきが見られるも のの, 分離型と一体型とはほぼ同様の関係のあることが 分かる。図中の奏線および破線は，それぞれの実験値を 最小二乗近似して求めた直線であって, 解析にはこれら の関係式を採用した。なお，同図にはSchultze ら ${ }^{6 /}$ が砂 の初期間隙比との関係で提案した関係直線 (一点鎖線) および対応する相対密度での上限線と下限線（点線）と を併記しておいた。筆者らの実験値はおおむね Schult ze らの提案する範囲に含まれるが，直線の勾配には違 いが見られる。

（2）枠および枠内土の先端抵抗と先端㶩下量との関係 図一5に，模型実験における枠先端の抵抗 $p_{p} \sim$ 沈下 量 $S_{\rho}$ 関係および枠内土先端の抵抗 $p_{s p}$ - 沈下量 $S_{s p}$ 関

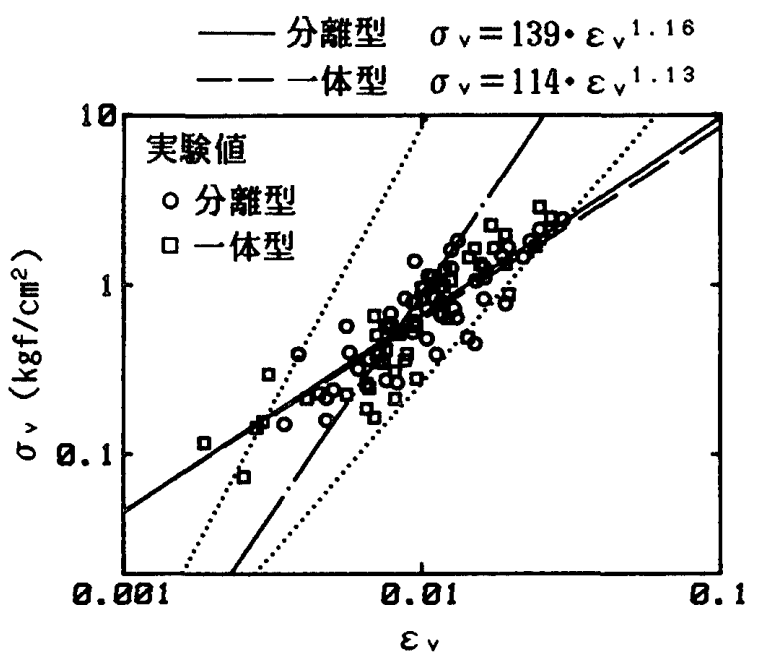

図一4 枠内土の鉛直応力 $\sigma_{v}$ 鉛直ひずみ $\varepsilon_{v}$ 関係図

（伜先端）

（伜内土先端）
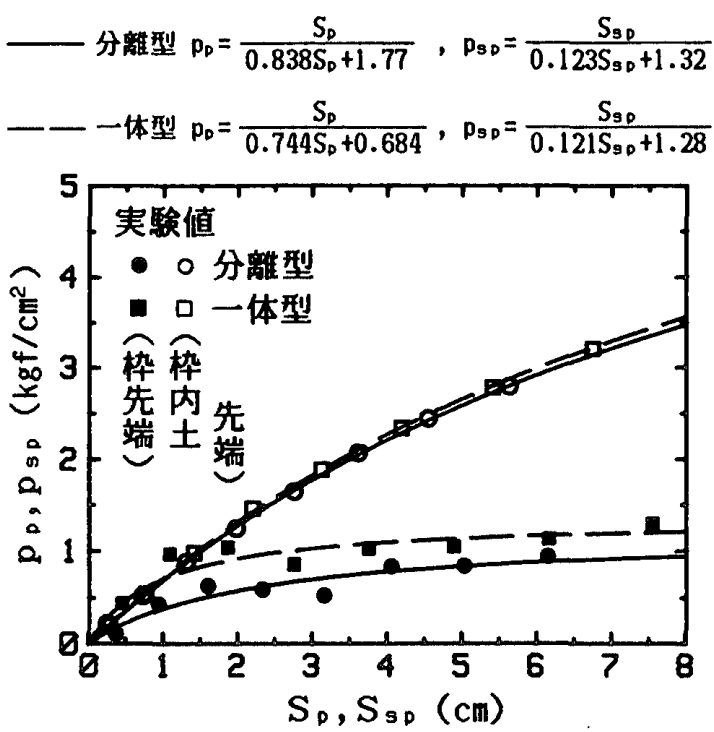

図一5 枠および枠内土の先端抵抗 $p_{p}, p_{s p}$ 一先端沈下量 $S_{p}$, $S_{s p}$ 関係図 
係を示した。同図において，枠先端と枠内土先端とでは， 沈下量の大きい範囲で抵抗值にかなりの差が見られる が，それぞれの分離型と一体型との間には顕著な差は認 められない。図中の実線および破線は，各々の関係を双 曲線関数で最小二乗近似した曲線である。先端抵抗〜先 端沈下量関係については，高次関数による近似 ${ }^{121}$ 等も考 えられるが，ここでは曲線の初期勾配や極限值の明確な Kondner 型の双曲線関数 ${ }^{131}$ を採用することとした。同図 より，各曲線は奉験值とよい対応を示していることが分 かる。

(3) 枠と地盤との間の摩擦応力と相対変位との関係

図一6は，分離型の載荷実験における枠外周面の平均 摩擦応力 $f_{0}$ と枠の沈下量 $S$ との関係をプロットしたも のであって，実験值を前項と同様の双曲線関数(4)で最小 二乗近似した曲線を実線で併記した。同一沈下量での $f_{o}$ が深さに一次的に比例するもの亡すれば，同曲線は 枠の中央深さ $(L / 2=30 \mathrm{~cm})$ での $f_{o} \sim S$ 関係亡考える ことができる。

そこで, 地盤の拘束圧と摩擦応力との関係を評価する ため, 中型単純せん断試験機151を用いてアルミニウム板 と砂との摩擦試験を奏施した。この試験機は,アルミニ ウム板を貼り付けた加圧板の上に，内法長さ $300 \mathrm{~mm}$, 幅 $200 \mathrm{~mm}$ ，高さ $150 \mathrm{~mm}$ のせん断箱（厚さ $20 \mathrm{~mm}$ の鋼 製フレーム 6 段重叔で，各フレーム間に $5 \mathrm{~mm}$ の隙間を 設けてある) を設置したものであって，加圧板でせん断 箱内の砂供試体に拘束圧をかけた後, 最上段のフレーム に毎分 $1 \mathrm{~mm}$ の変位速度でせん断力を加えることができ る。砂供試体は, 模型実験の地盤とほぼ等しい相対密度 となるよう，多重ふるい付きサンドレイナーによって作 製した。またアルミニウム板は，模型枠と同じ表面粗さ $\left(R_{\max } \fallingdotseq 2.0 \mu \mathrm{m}\right.$ ，基準長さ $\left.0.8 \mathrm{~mm}\right)$ のものを使用した。 図一7は，3 種類の拘束圧 $\sigma_{n}$ のもとでの試験結果を示し たものであって，横軸は最下段フレームとアルミニウム 板との相対変位 $\delta_{s}$ を, 縦軸は摩擦応力度 $\tau$ を表してい る。図中の実線は $\sigma_{n}=1.095 \mathrm{kgf} / \mathrm{cm}^{2}$ の結果を双曲線関

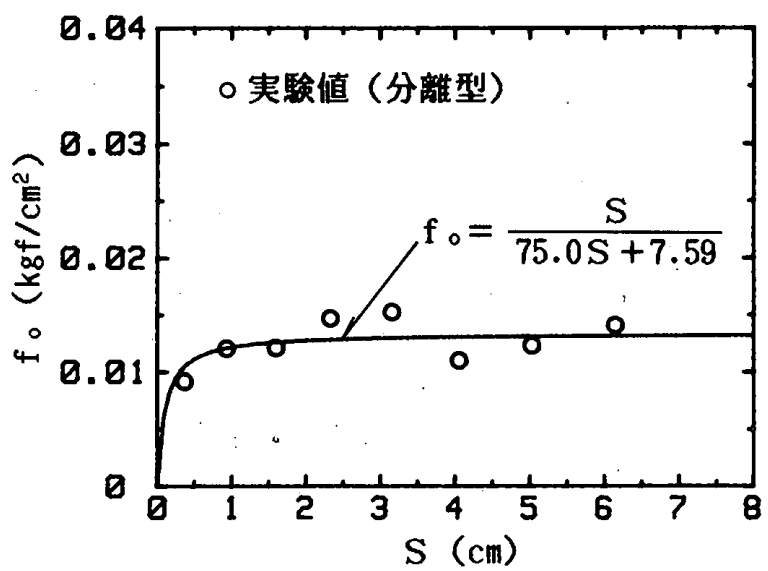

図一6 枠外周面の平均摩擦忘力 $f_{o}$ 一枠の沈下量 $S$ 関係図
数で最小二乗近似して求めた曲線である。この曲線式を 基準として， $\sigma_{n}$ の比率で $\tau$ が増娍するものと仮定して 他の $\sigma_{n}$ の場合を描いたのが同図中の点線である。各実 験值と曲線とはよい対忘を示していることが分かる。

以上より，枠外周面については，図一6の $f_{o} \sim S$ 関係 曲線を基準として，各節点深さでの地盤の水平応力 $K \gamma Z$ ( $Z$ : 地表面からの梁さ) の大きさに応じて次の関 係曲線が成立つものとした。

$$
f_{o}=\frac{S}{75.0 S+7.59} \times \frac{K \gamma Z}{K \gamma L / 2}
$$

また染内面については，(14）式と同様の（15）式を採 用することとし，枠内土の水平応力 $K \sigma_{v}$ の大きさに対 态して関係曲線が変化するものとした。

$$
f_{i}=\frac{\Delta S}{75.0 \Delta S+7.59} \times \frac{K \sigma_{v}}{K \gamma L / 2}
$$

ここで，K 值は文献 9）の静止土王係数に関する実験結 果を参考として， Jáky ${ }^{36)}$ の提案式による $K=1-\sin \phi$ $=0.46\left(\phi=33^{\circ}:\right.$ 三軸圧縮試験にようて求めた地盤の 内部摩擦角) が枠の内外の全長にわたって成立つものと した。

なお，一体型については，外枠のひずみ测定値に乱れ が見られたため ${ }^{2 !} ， f_{0}$ は分離型の場合と同等として，(14)

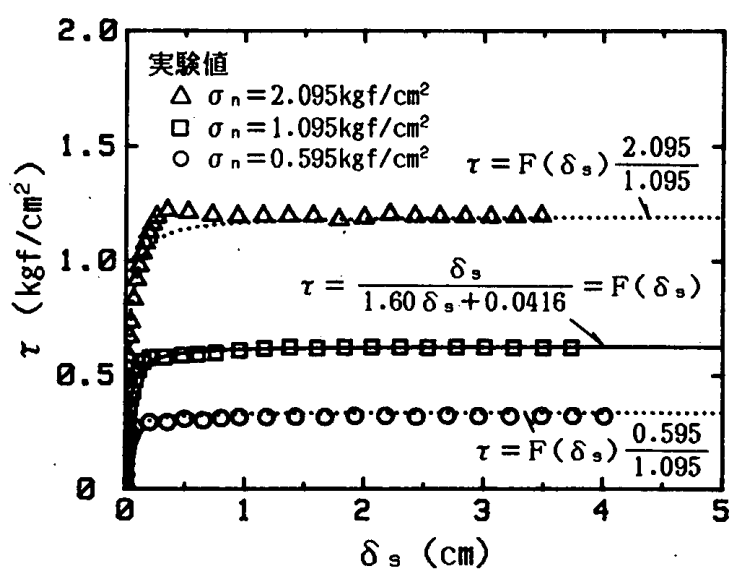

図一7摩擦試験での摩擦态力度 $\tau \sim$ 相対変位 $\delta_{s}$ 関係図

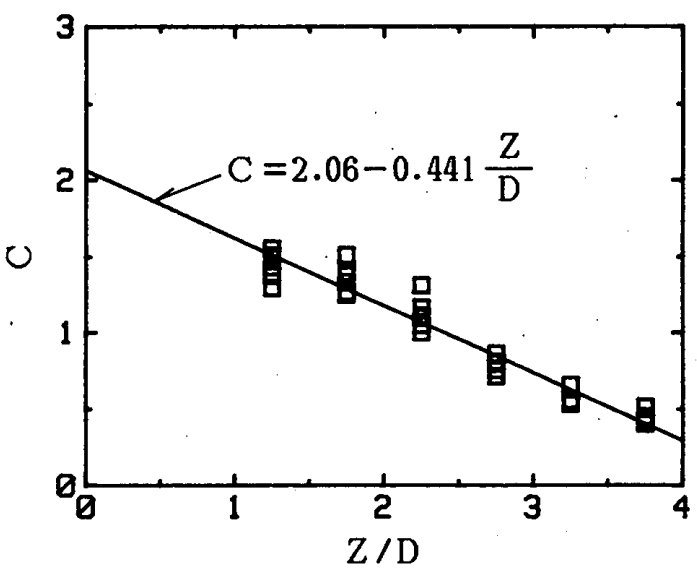

図一8 摩擦応力 $f_{i}$ の補正係数 $C \sim Z / D$ 関係図 (一体型) 


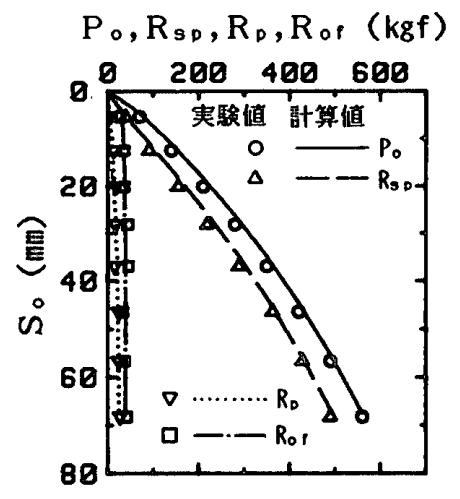

(a) 荷重,各抵抗 載荷板沈下量 $\mathrm{S}$ 。関係

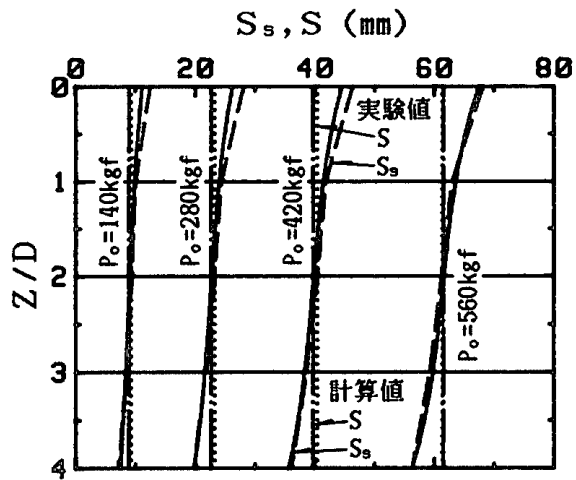

（b）枠内土および杂の沈下量分布

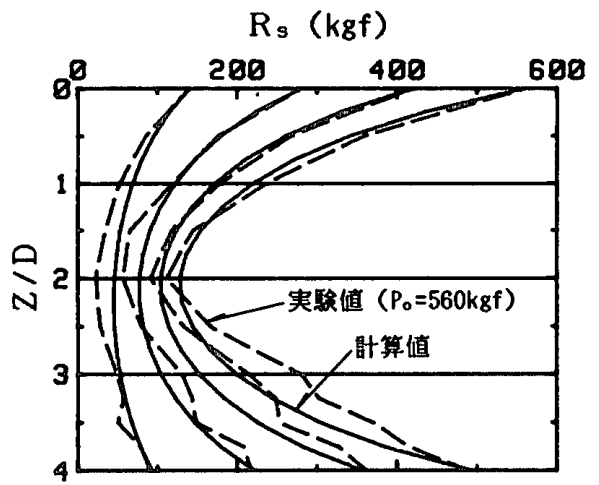

（c）伜内土の軸方向力分布

図一9 分離型の計算值と実験値との比較図

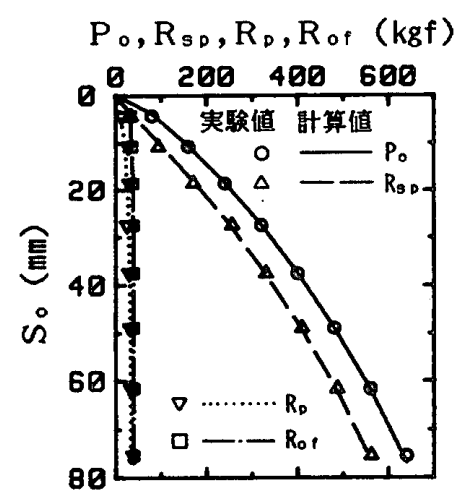

(a) 荷重,各抵抗 臷荷板沈下量 $\mathrm{S}$ 。関係

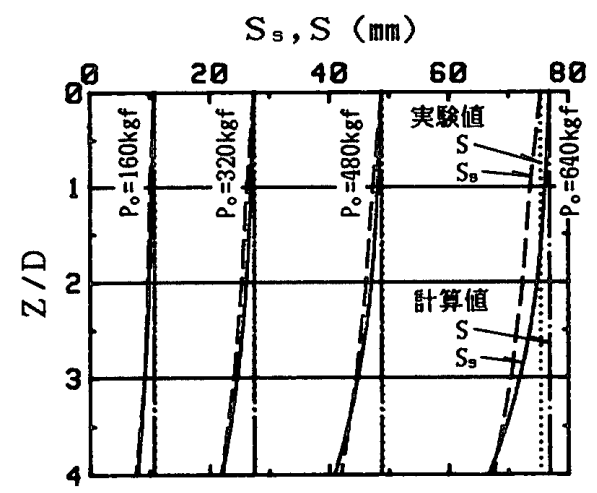

（b）枠内土およU゙枠の沈下量分布

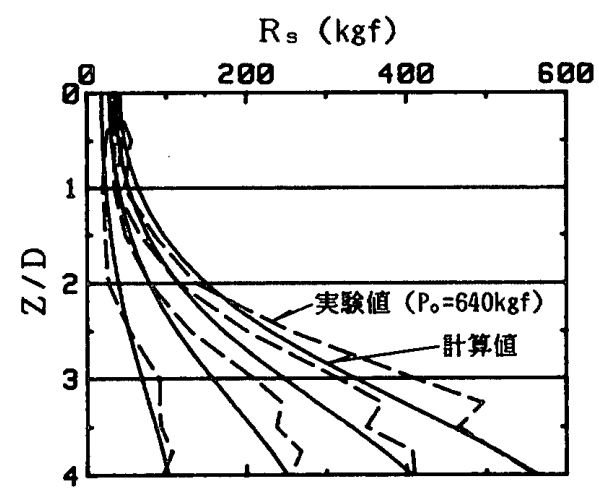

（c）枠内土の軸方向力分布

図一10 - 体型の計算値と実験値との比較図

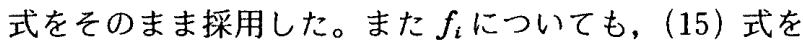
採用することとしたが，実験值との間の誤差が生じたた め, 以下の補正を行った。図一8は, 前述（1）の滑ら かな曲線近似による枠内土の軸方向力分布から求めた $0.5 D$ 区間ごとの平均摩擦応力の，(15）式による $f_{i}$ に 対する比 $C$ と $Z / D$ との関係を示したものである。た だし，摩擦応力が小さく計算誤差が大きい第 1 および第 2 荷重階と上部 $1 D$ 間の值は除外してある。同図より, ある程度のばらつきはあるものの，Cは深さに伴って ほぼ直線的に減少していることが分かる。この原因につ いては不明確であるが，フーチング底面直下の局部応力 などによるものと推察される。ここではこれらの值を直 線で最小二乗近似した図中の実線の関係を補正係数 $C$ として，(15）式に乗じて解析に採用することとした。

\section{2 解析結果}

分離型の計算結果を図一9に，一体型の計算結果を図 -10に，実験値と併せて示す。各々 (a)図は, 載荷荷 重 $P_{0}$, 枠内土先端抵抗 $R_{s \rho}$, 枠先端抵抗 $R_{p}$ および枠外 周面摩擦抵抗 $\boldsymbol{R}_{o,}$ と基礎フーチング（載荷板）の沈下 量 $S_{0}$ との関係を, (b)図は, 枠内土の沈下量 $S_{s}$ および 枠の沈下量 $S$ の $Z / D$ 方向の分布を，また (c)図は，枠 内土の軸方向力 $R_{s}$ の分布を示したものである。なお,
一体型については，前述のごとく外枠のひずみ測定値に 乱れがあるため, 図一10(a) の $R_{o r}$ の実験値は, 分離 型の場合と同等として算出してある。(a) および (b) 図より，分離型・一体型ともに，計算値は実験值と非常 によい一致を示していることが分かる。(c)図において は，実験値にある程度の乱れが見られるものの，計算値 と実験值とはかなりよい対応を示していると言える。

以上より，本理論解によって，模型枠基礎の鉛直載荷 実験における荷重一沈下量関係や枠内土の沈下量分布お よび軸方向力分布を十分に精度よく表現できることが分 かった。

\section{4. 枠基礎の荷重〜沈下特性}

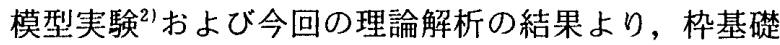
の荷重一沈下特性として, 枠外周面の摩擦抵抗および枠 先端肉厚部の抵抗の影響は小さく，枠内土および枠内土 先端下部地盤の圧縮性が支配的とみてよい。その際，枠 内土の軸方向力および枠と枠内土との相対変位は, 分離 型では枠内土の上端および先端より中央深さに向かっ て，一体型では枠内土先端より上方に向かってそれぞれ 娍少し，ある距離においてほぼ 0 に収束する。ただし， この距離は，枠の内径および表面粗度，枠内土の土質条 
件などによって当然変化するものと考えられる。した がって，以下この值を $L_{c}$ と表現し，各型式での枠の根 入れ長さ $L$ の違いによる荷重一沈下特性に関して考察 する。

\section{(1) 分離型}

$L<2 L_{c}$ の場合を図一11(a)に, $L \geqq 2 L_{c}$ の場合を図 一11(b) に示した。図中の記号 $S_{F}$ は，枠を剛体とみな しての沈下量を表す。いずれも，枠内土は中央深さにお いて枠と固定されたのと同等の状態で上端および先端よ り圧縮される。 $L<2 L_{c}$ の場合，枠内土の軸方向力 $R_{s}$ は中央深さにおいて0にはなりきらない。したがって， 基礎フーチングの沈下量 $S_{0}$ は，枠で拘束された $L / 2$ の 長さの地盤の圧縮量の 2 倍と，下部地盤の沈下量との和 となる。 $L \geqq 2 L_{c}$ の場合は, 枠内土上端および先端より それぞれ $L_{c}$ 付近で $R_{s}$ は 0 に収束し，以避の中央部分 は初期の地盤状態のまま,枠とともに剛体的に沈下する。 $S_{\mathbf{0}}$ は; 枠で拘束された上下各 $L_{c}$ 間の地盤の圧縮量と, 下部地盤の沈下量との和と考えることができる。

\section{（2）一体型}

枠内土は上端が枠と固定された状態で先端より押上げ られる。 $L<L_{c}$ の場合と $L \geqq L_{c}$ の場合とに分けられ， 枠内土の圧縮状態は，2 倍の根入れ長さをもった分離型 での下半分と等しい。すなわち, 図一12に示した関係 が成り立つ。同図(b) の $L \geqq L_{c}$ の場合には, 枠内土先 端より $L_{c}$ の位置で $R_{s}$ は 0 に収束し，それ以浅では載 荷荷重の $100 \%$ を枠が支持する。 $S_{0}$ は (a)，(b) いず れの場合も, 枠内土の圧縮量と下部地盤の沈下量との和 となることは, 分離型の場合と同様である。

\section{（3）枠のみに荷重が作用した場合}

比較として，枠のみに荷重が作用した場合を考える。 $L<L_{c}$ の場合と $L \geqq L_{c}$ の場合とに分けて図一13に示し た。枠内土は上端が開放された状態で先端より押上げら れる。 $L<L_{c}$ の場合は，枠と枠内土上端とにずれを生じ， 枠内面の摩擦抵抗が発揮されにくい。 $S_{0}\left(=S_{F}\right)$ は, 枠外周面の摩擦抵抗および枠先端肉厚部の抵抗によって 規定される沈下量の割合が比較的大きい。 $L \geqq L_{c}$ の場 合は, 枠内土の閉塞効果により, 枠内土上端と枠とが一 体となって沈下する。 $R_{s}$ は先端より $L_{c}$ の位置で 0 に 収束し，一体型の場合と同等の荷重～沈下性状を示す。

以上において， $L_{c}$ 間の枠内土の圧縮量は, 側方拘束 状態の土の圧縮試験あるいは理論解析によって評価する ことができる。この場合, 文献 1) の実験結果および解 析結果にも見られたように，荷重の増加に伴って枠内土 の剛性は増大し，枠が健全である限り，粒子破壊に至る まで堪えることができる。したがって，支持力的には， 載荷面が枠の先端深さにあって, 外周面の摩擦抵抗が等 しい直接基礎と同等と評価できる。また，枠内土の王縮 量は，基礎フーチングの沈下量に対してかなり小さく，

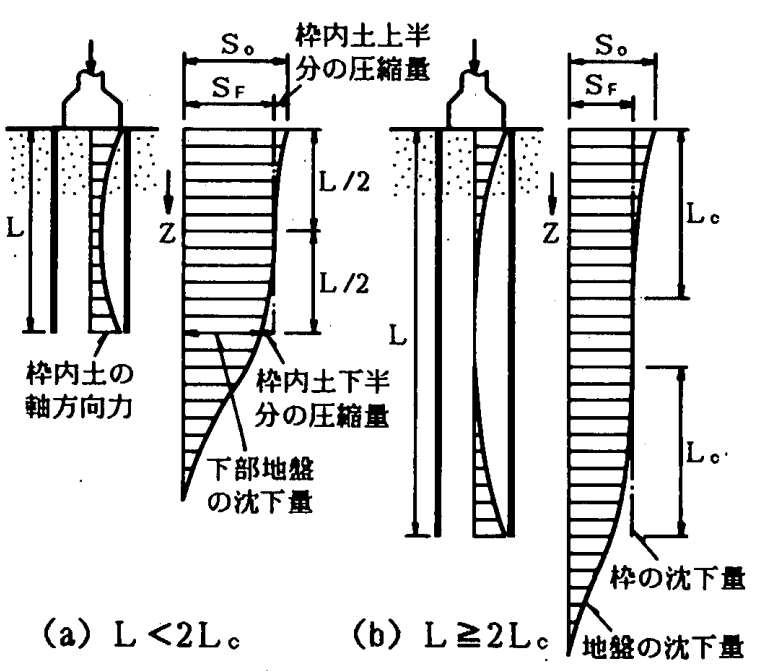

図一11 分離型枠基礎の沈下性状

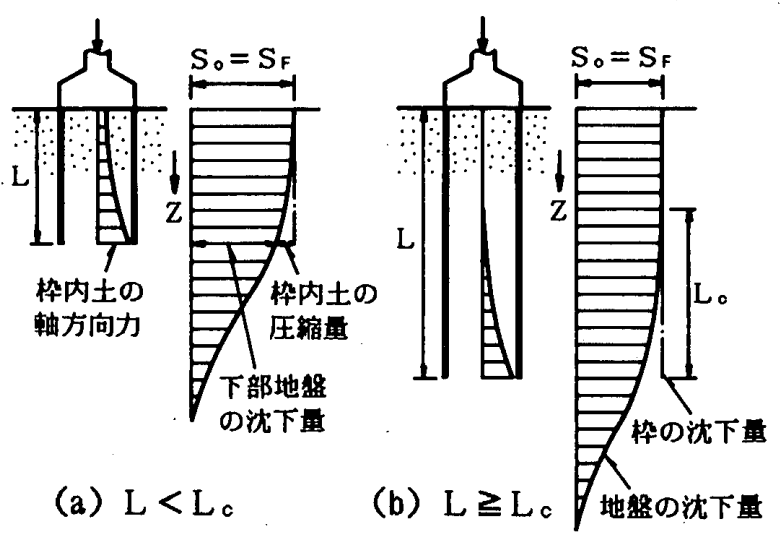

図一12 一体型枠基礎の沈下性状
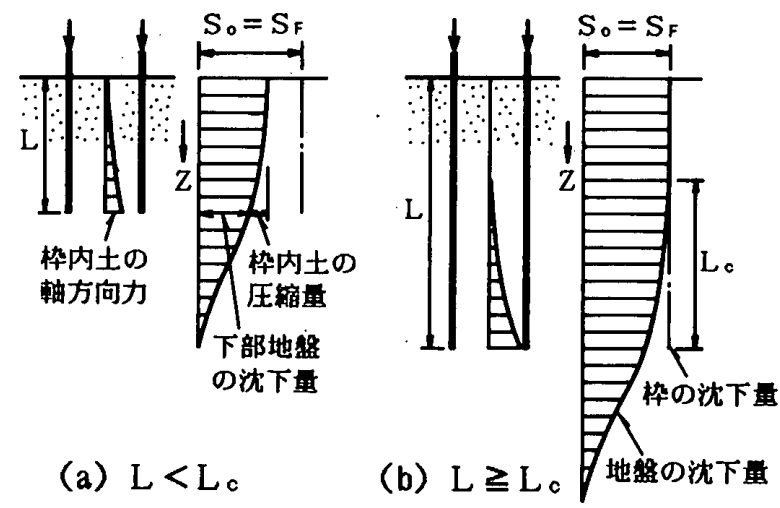

(a) $\mathrm{L}<\mathrm{Lc}$

重が作用した場合の视下性状

図一13枠のみに荷重が作用した場合の沈下性状

沈下量の大部分を枠内土下部地盤の沈下が占める。この ため, 分離型と一体型とでは, 同一荷重時の沈下量の差 は小さい。定量的には，枠根入れ長さが $2 L_{c}$ 以上の場合， 分離型の方が上部 $L_{c}$ 間の枠内土の圧縮量分だけ一体型 より沈下量が大きいと考えることができる。

\section{5. 結 語}

以上本論文では，枠基礎の鉛直支持力機構に関する理 論解を提示し,模型実験の結果と比較することによって， 
理論解の妥当性の検討を行った。また，既報 ${ }^{11,2)}$ の実験 結果を含めて, 枠基礎の荷重一沈下特性の総括的な考察 を行った。結論として，以下のことが指摘できる。

(1) 枠および地盤に区分法を適用し, 差分方程式を誘導 する方式による本理論解によって，模型実験での荷重〜 沈下量関係や枠内土の沈下量分布および軸方向力分布を よい精度で表現できた。

(2) 枠基礎は, 枠外周面の摩擦抵抗および枠先端肉厚部 の抵抗の影響は小さく，枠内土および枠内土先端下部地 盤の圧縮性が支配的である。その際, 枠内土は荷重の增 加に伴って剛性が増大するため，支持力的には，枠の根 入れ長さと同じ根入れの直接基礎と同等と評価された。 (3) 基礎フーチングの沈下量は，枠内土の王縮量と下部 地盤の沈下量との和であって，沈下量の大部分を下部地 盤の沈下量が占めるものの, 載荷型式および枠根入れ長 さの違いによって，図一11 および図一12 に示す地盤の 沈下量分布になるものと結論づけられた。

\section{参考文献}

1）伊藤淳志, 山肩邦男：鋼管で側方拘束された砂柱の忘力 . 変形特性の検討, 日本建築学会構造系論文報告集，第 392 号, pp. 98 107, 昭和 63 年 10 月

2）伊藤淳志，山肩邦男：枠基礎の模型実験結果ならびに枠 内土の挙動に関する考察，日本建築学会構造系論文報告 集, 第 409 号, pp. 123 132, 平成 2 年 3 月

3）南 和夫：筒基礎の研究，日本建築学会諭文報告集，第 39 号, pp. 1 17, 昭和 24 年 11 月

4) Kuzmanović, B. O. and Balla, A. : Spread footings on "reinforced" soil, Canadian Geotechnical Journal, Vol. 7, No. 3, pp. 318 326, 1970.8

5). Broms, B. B., Ivmark, G. and Mattson, A. : Tubular Elements as Foundation for Structures, Proc. 10th ICSMFE, Vol.2, pp. $61 \sim 66,1981.6$
6) Schultze, E. and Moussa, A. : Factors affecting the Compressibility of Sand, Proc. 5th ICSMFE, Vol.1, pp. $335 \sim 340,1961.7$

7) 山原 浩：鋼管ぐいの閉塞効果と支持力機構（その2), 日本建築学会諭文報告集, 第 97 号, pp. 34 41, 沿和 39 年 4 月

8) Mayne, P.W. and Kulhawy, F.H. : $K_{0}-\mathrm{OCR}$ Rela tionships in Soil, Jour. Geotech. Eng. Div., ASCE, Vol. 108, No. GT6, pp. 851 872, 1982.6

9) 山肩邦男, 伊藤淳志, 奥野哲也 : 鋼管で側方拘束された 砂柱の静止土王係数, 第 24 回土資工学研究発表会, pp. 1427 - 1430, 平成元年 6 月

10）山肩邦男：建築基礎工学, 朝倉書占, pp. $129 \sim 133$, 平 成 2 年 4 月

11）岸田英明, 高野昭信：砂地盤中の埋込み杭先端部の接地 压分布（その2. 接地压分布と埋込み杭の先端支持力の関 (係), 日本建築学会論文報告集, 第 261 号, pp. $25 \sim 40$, 昭和 52 年 11 月

12）山肩邦男, 伊藤淳志：場所打ちコンクリート杭の極限先 端荷重および先端荷重一先端沈下皓曲線について, 日本 建築学会大会学術講演梗概集 B, pp. 1279 - 1280, 沿和 61 年 8 月

13) Kondner, R. L. : Hyperbolic Stress-Strain Response: Cohesive Soils, Jour. Soil Mech. and Found. Div., ASCE, Vol.89, No.SM1, pp.115 143, 1963.2

14）山肩邦男, 永井興史郎：杭の周面摩擦応力度 $f$ 沈下量 $S$ 関係の近似式とその統計值, 日本建築学会大会学術講 演梗概集, pp. 2315 2316, 昭和 56 年 9 月

15）山肩邦男, 小棕仁志, 伊藤淳志, 加藤史彦 : 中型単純せ ん断試験機を用いた砂一モルタル板間の摩擦試験, 日本 建築学会大会学術講演梗概集 B, pp. 1409 1410, 平成元 年 10 月

16) Jáky, J. : Pressure in Silos, Proc. 2nd ICSMFE, Vol. 1, pp. 103 107, 1948. 6

(1990 年 9 月 26 日原稿受理, 1990 年 12 月 5 日採用決定) 